\title{
Economic essence and architectonics of resource potential of agricultural enterprises: theoretical aspect
}

\author{
Ivaniv S. \\ Vasyl Stefanyk Precarpathian National University \\ 57, Shevchenka Str., Ivano-Frankivsk, 76000, Ukraine \\ e-mail: feya8246@ukr.net \\ ORCID: 0000-0001-6743-0804 \\ * Supervisor - Doctor of Economics D.I. Shelenko
}

Goal. To study the essence of the concept of «resource potential» of agricultural enterprises and analyze its architecture. Methods. Abstract, method of thematic analysis, synthesis, and grouping to determine the basic principles of resource efficiency. Results. Approaches to the interpretation of the category «resource potential» of agricultural enterprises are grouped. The own definition of the concept of «resource potential» is given, taking into account the specifics of conducting the activities of agricultural enterprises. The structure of resource potential has been supplemented with an information support component. Conclusions. It was determined that to characterize the category of «resource potential» it is necessary to study the resource base of an agricultural enterprise and analyze the opportunities that can be used to obtain economic benefits. It is important to consider the resource potential not only as a set of available resources, but also to take into account the system of productive forces, capabilities, and abilities of employees to use resources efficiently and appropriately. The conditions under which the resource potential is used also play an important role. The degree of favorable conditions depends on the efficiency of the use of resource potential.

Key words: agricultural sector, finance, personnel, land resources, technical support.

DOI: https://doi.org/10.31073/agrovisnyk202105-11

Enterprises engaged in agricultural economic production, have all opportunities to bring the agricultural sector to positions, taking into account the quality of land reserve of Ukraine. However, only land resources as a basis can't provide high profits and access to inter the people's market, because important are also terms of use not only land resource, but also the whole base of available resources.

The application of practical actions for the use of resource potential is preceded by a theoretical understanding of its essence main components. The application of practical actions for the use of resource potential is preceded by a theoretical understanding of its essence main components. Moreover, there is a need to supplement and rethink existing interpretations of the concept of "resource potential", given the rapid changes in the economy and approaches to agriculture.

In view of this, the interest of scientists in the agricultural field in studying the category of "resource potential" and the peculiarities of its use by agricultural enterprises is growing. Thus, researchers consider the definition of "resource potential" through the prism of elements and group these elements into components, thus reflecting the structure of resource potential [1, 2], explain the essence of the constituent elements: financial, material, intangible, information, human, technical and technological resources , emphasizing the importance of understanding the formation of the resource base of the enterprise [3], pay attention to foreign experience of the forming of potential (in the USA, Japan, Germany, Great Britain), compare with domestic practice and suggest ways to adapt foreign experience in Ukrainian enterprises, given the unstable economic situation [4].

The purpose of research is to find out the essence definition of "resource potential" of agricultural enterprises, to determine and analyze the main components of resources potential, define as affected by the peculiarities of agricultural business enterprises on structure resource potential.

Materials and methods of research. To get acquainted with the variability of theoretical interpretations of researchers on the essence of the definition of "resource potential" used the method of thematic analysis. The formation of one's own definition of the concept of "resource potential" became possible through the use of abstract-logical method. Using the grouping method, the basic principles of resource efficiency were identified.

Research results and their discussion. Resource potential is a category that affects the development of agricultural enterprises and their competitiveness, given the rapid development of the economy, transformations in land legislation and abrupt, unpredictable changes in modern society. Because the enterprises of the agricultural sector use land resources for production, it is necessary to focus on the effectiveness of their use in the context of sustainable development.

For the effective use of resource potential, it is important, first of all, to understand the essence of the concept of "resource potential". Researchers consider the resource potential as a component of the economic potential of the enterprise, presenting resources as a basis [5,6]. In particular, there is a definition of the potential of the enterprise that the potential of the enterprise is a totality of capabilities of the resource set of the enterprise and its competencies to achieve the desired economic goal for stakeholders by doing business processes [5]. From this definition it is not entirely understand what kind of resource set the author means. We also think that achieving economic goals is possible not only through business processes, because such an interpretation is quite narrow. For example, you can get economic benefits by organizing training courses for employees, which is not a business process. 
Some authors argue that resource potential is a system of interconnected different types of resources belonging to the enterprise, or those that can be involved in its economic activity to maximize the needs of consumers and increase its competitiveness in the market [7]. We consider that this definition is incomplete, because the researcher focuses only on the totality of resources, without taking into account the opportunities that the company will be able to obtain in the process of their use.

In the process of studying this issue, researchers note that the effective use of resource potential of the enterprise is an increase in return on capital assets, which in modern conditions is complicated by rapid changes in equipment and increased capital investment to improve working conditions and others. [8].

The definition of "resource potential" is interpreted differently by scientists: some consider resource potential only as a set of available resources [7,9], others see this category as a system based on the use of productive forces [10,11], or interpret resource potential as a set of available resource base, opportunities that can be obtained by the company, using appropriate resources, as well as the ability of staff to apply resources $[3,12,13]$.

In particular, we think that the extensive definition of resource potential is a totality of resource capabilities, managerial abilities and motivation of an entrepreneur; in addition, employees must influence external changes in order to improve the company's performance in a competitive environment [3].

Thus, the resource potential of agricultural enterprises is a system based on the relationship of resources (tangible, intangible, financial, personnel and information), which have their own characteristics and elements, capabilities of the enterprise, competencies, skills of management that will allow to improve the financial situation of agriculture, to be realized in the business environment, to strengthen its competitiveness and to realize strategic goals.

The elemental composition and features of the structure of resource potential provide an opportunity to better understand its essence and structure.

Elements of the resource potential of an agricultural enterprise are a set of its components, namely labor, financial, material and intangible, information resources, as well as resources consisting of non-current and current assets.

In the work of V.M. Hrynova and M.M. Salun elements of resource potential are proposed to be considered in terms of the following components: logistical, labor, financial and intangible [1]. In turn, O.V. Latysheva complements this grouping with ecological and social components [2].

Material and technical structural elements reflect the set of fixed assets (funds) and current assets that provide the production component of agriculture. The most important among these resources is land, because the lack of this resource for enterprises in the agricultural sector makes practical activities impossible.

The work structure is a set of components of human resources: knowledge, skills and opportunities for the development of new skills by employees. We consider that the effectiveness of labor potential depends on the following factors: the level of competence of employees, provision of material and technical base, climate in the team, the degree of trust of management to employees, staff understanding of strategic objectives and the ability of management to meet employee needs.

Financial capital, which is pledged at the establishment of agriculture, attracted and obtained as a result of economic activity (sale of manufactured products or provision of services in the field of tourism), as well as property owned or raised on a contractual basis, are elements that form the financial part.

Elements of the intangible component resource potential are patents (in agricultural enterprises there may be patents for a special method of land cultivation, the invention of new technical means for this purpose, animal feeding or plant growing methods), brand name of the produced agricultural product, "know-how" and trade secrets.

The authors in their study also include information resources in intangible resources [2]. However, we believe that if we distinguish between environmental and social components, we should include information resources (regulatory framework, instructions on production technology, tillage, plant growing, animal care, accesses to Internet resources) to the elements of the information component.

The analysis of the use of resource potential becomes more detailed if we consider the environmental and social components separately. Ecological component in modern economic conditions is determined by the ability to apply modern eco-approaches to agriculture: the use of resource-saving technologies, economic and environmental innovations in the agricultural sector and the development of environmental management.

Elements of the social component no less important and have a close relationship with labor resources, because social guarantees (health insurance, paid annual leave, the possibility be on sick leave, standardized working day), material bonuses besides encourage employees to be more honest perform their duties.

Resource potential is directly related to indicators of business efficiency. An important factor in assessing the effectiveness of the use of resource potential is the choice of appropriate indicators. In their study, a number of authors point to the possibility of using an integrated approach, which allows you to select indicators in subindices and get a single integrated performance indicator. This significantly simplifies the process of assessing the effectiveness of the use of resource potential by agricultural enterprises [14].

Resource potential should be used based on such principles as systemicity, rationality, structure, economic orientation, environmental friendliness, adequacy, purposefulness, social justice, coherence [15].

Activities of enterprises wich providing society with agricultural products, has a number of sectoral features of resource potential: natural (seasonality, climate change, land use as a priority resource); production (significant volumes of work in progress, difficulty in determining the cost, use of stocks with low mobility); financial (increased need for credit resources, the formation of a reserve of funds to pay rent for the land, the difficulty in determining the need for financial resources); organizational and technical (the need for annual 
renewal of logistics, differences between the periods of incurred costs and income, a large number of leased assets).

Thus, resource potential as a category is important to consider through the prism of its elements and taking into account the specifics of the industry in which the company operates, because it can cover the entire category, understand how to improve resource utilization and increase efficiency.

\section{Conclusions}

The resource potential of agricultural enterprises reflects all available resources or those that need to be attracted in accordance with the set tactical or strategic goals, and all the opportunities that the company may receive from the efficient use of the resource base. Elements of resource potential form its structure taking into account specific features of function. The resource base is formed from labor, financial, material, intangible and information resources. Given the concept of sustainable development, social and environmental components become important, because they expand the completeness of the category of resource potential of agricultural enterprises and create reserves for it using. The efficiency of the use of resource potential by agricultural enterprises depends on the characteristics that accompany their activities, namely: natural, production, organizational, technical and financial.

\section{References}

1. Hrynova, V. M., \& Salun, M. M. (2005). Orhanizatsiia vyrobnytstva [Organization of production]. The manual. Kharkiv: INZHEK [in Ukrainian].

2. Latysheva, O. V. (2018). Resursnyi potentsial pidpryiemstva: sutnist, skladovi ta osoblyvosti upravlinnia elementamy zabezpechennia staloho rozvytku [Resource potential of the enterprise: essence, components and features of management of elements of maintenance of sustainable development]. Economic Bulletin of Donbass, 3, 126-130 [in Ukrainian].

3. Buhai, V. Z., Horbunova, A. V., \& Kliuieva, Yu. V. (2011). Teoretychni osnovy formuvannia potentsialu pidpryiemstva [Theoretical bases of formation of potential of the enterprise]. Bulletin of Zaporizhia National University, 1, 27-33 [in Ukrainian].

4. Shostak, L. V. (2015). Zarubizhnyi dosvid formuvannia potentsialu pidpryiemstva [Foreign experience in building the potential of the enterprise]. Bulletin of the National University "Lviv Polytechnic», 819, 449-454 [in Ukrainian].

5. Krasnoutska, N. S. (2004). Potentsial pidpryiemstva:formuvannia ta otsinka [Enterprise potential: formation and evaluation]. The manual. Kharkiv: KHDUKHT [in Ukrainian].

6. Lapin, Ye. V. (2002). Ekonomichnyi potentsial pidpryiemstva yak ekonomichna katehoriia [Economic potential of the enterprise as an economic category]. Scientific Bulletin of the Chernivtsi Trade and Economic Institute KNTEU, 2, 380-385 [in Ukrainian].

7. Mitsenko, N. H., \& Kumechko, O. I. (2010). Resursnyi potentsial pidpryiemstva: sutnist, struktura, stratehiia vykonannia [Resource potential of the enterprise: essence, structure, strategy of execution]. Scientific Bulletin of NLTU of Ukraine, 20(9), 193-198 [in Ukrainian].

8. Szabolcs, N., \& Pererva, P. (2018). Efficiency of use of resource potential. Strategic and innovative development of the economic system in the context of globalization. Kharkiv.

9. Serdak, S. E. (2008). Pryntsypy efektyvnoho upravlinnia resursamy sub'iektiv hospodariuvannia [Principles of effective management of resources of economic entities]. Academic review, 2, 83-88 [in Ukrainian].

10. Honchar, M. V. (2016). Obgruntuvannia strukturyzatsii resursnoho potentsialu pidpryiemstva [Substantiation of structuring the resource potential of the enterprise]. Scientific Bulletin of Polissya, 2, 108113 [in Ukrainian].

11. Tsymbal, O. I. (2010). Sutnist ta pidkhody shchodo otsiniuvannia trudoresursnoho potentsialu promyslovosti $v$ konteksti rehionu [The essence and approaches to assessing the labor potential of industry in the context of the region]. State and regions, 5, 78-84 [in Ukrainian].

12. Bahatska, N. M. (2016). Suchasnyi pidkhid do otsinky sutnosti resursnoho potentsialu pidpryiemstva [A modern approach to assessing the essence of the resource potential of the enterprise]. Economy and society, 3, 134-139 [in Ukrainian].

13. Nevrotskyi, N. O. (2017). Otsinka efektyvnosti vykorystannia resursnoho potentsialu pidpryiemstva [Estimation of efficiency of use of resource potential of the enterprise]. Interscience, 1(23), 97-101 [in Ukrainian].

14. Balaniuk, I. F., Shelenko, D. I., Biloshkurskyi, M. V., Povorozniuk, I. M., \& Slatvinska, L. A. (2021). Intehrovanyi pidkhid do otsinky efektyvnosti biznesu pidpryiemstv [integrated approach to evaluation of business efficiency of enterprises]. Theory of management and research of rural business and infrastructure development, 42(4), 486-496 [in Ukrainian].

15. Kustrich, L. O. (2017). Osnovni zasady pidvyshchennia efektyvnosti upravlinnia ta vykorystannia potentsialu silskohospodarskykh pidpryiemstv [Basic principles of improving the efficiency of management and use of the potential of agricultural enterprises]. Scientific Bulletin of Kherson State University. Ser. Economic sciences, 27(2), 19-22 [in Ukrainian]. 